Copyright (C) 2016 SBPjor / Associação Brasileira de Pesquisadores em Jornalismo
RESEARCH METHODOLOGIES APPLIED TO JOURNALISM: A study of the papers presented in
SBPJor (2003-2007)

ELIAS MACHADO

Universidade Federal de Santa Catarina, Brazil JÚLIA ROHDEN

Universidade Federal de Santa Catarina, Brazil

\begin{abstract}
In this article we analyze the 509 papers that have been presented at conferences from the Brazilian Association of Researchers in Journalism (SBPJor) between 2003 and 2007. The analysis was made from four reference categories: 1) types of research, 2) formal standardization, 3) kind of methodological matrices and 4) level of training of authors. The goal is to identify the level of professionalization of specialized journalism studies, highlighting the types of research and manuals, theoretical influences and predominant methodological matrices. Among the main results, we note the predominance of doctor authors and of empirical research. We also note the lack of suitability for formal standardization.
\end{abstract}

Key words: Methodologies. Research in Journalism. Method Research. Methodological matrices

\title{
METODOLOGIAS DE PESQUISA APLICADAS AO JORNALISMO: Um estudo dos trabalhos apresentados na SBPJor (2003-2007)
}

RESUMO - Neste artigo analisamos os 509 trabalhos que foram apresentados em congressos da Associação Brasileira de Pesquisadores em Jornalismo (SBPJor) entre 2003 e 2007. As análises foram feitas a partir de quatro categorias de referência: 1) tipos de pesquisa, 2) padronização formal, 3) tipo de matrizes metodológicas e 4) nível de formação dos (as) autores (as). O objetivo é identificar o nível de profissionalização dos estudos especializados em jornalismo, destacando os tipos de pesquisa e de manuais, as influências teóricas e as matrizes metodológicas predominantes. Dentre os principais resultados, ressaltamos a predominância de autores doutores e de pesquisas empíricas. Observamos também a falta de adequação à padronização formal.

Palavras-chave: Metodologias. Pesquisa em Jornalismo. Método de Pesquisa. Matrizes Metodológicas. 


\section{METODOLOGÍAS DE INVESTIGACIÓN APLICADA AL PERIODISMO: Un estudio de los trabajos presentados en SBPJor (2003-2007)}

RESUMEN - En este artículo se analizan los 509 trabajos que se han presentado en las conferencias de la Asociación Brasileña de Investigadores en Periodismo (SBPJor) entre 2003 y 2007. El análisis se hizo a partir de cuatro categorías de referencia: 1) tipos de investigación, 2) la normalización formal, 3) tipo de matrices metodológicas y 4) el nivel de formación de los (las) autores (as). El objetivo es identificar el nivel de profesionalización de los estudios de los investigadores en periodismo, destacando los tipos de investigación y manuales, influencias teóricas y matrices metodológicas predominantes. Entre los principales resultados, se observa el predominio de los investigadores doctores y estudios con investigación empírica. También observamos la falta de rigor en la normalización formal. Palabras clave: Metodologías. Investigación en Periodismo. Método de Investigación. Matrices metodológicas.

\section{Introduction}

Over the years, we have discussed the mapping of methodological theory used by Brazilian researchers in Journalism (MACHADO, 2005; 2010; MACHADO; SANT'ANNA, 2014; MACHADO; ROSA SILVA, 2014, MACHADO; ROHDEN, 2014). This paper is a continuation of our previous analysis (MACHADO; ROHDEN, 2014) on papers presented at conferences for the Brazilian Association of Researchers in Journalism (SBPJor) between 2003 and 2004. We followed that analysis up with another analysis of 354 papers presented between 2005 and 2007. This article presents the collective analysis of the 509 total papers presented during the first five years of SBPJor conferences (2003-2007). The end result is to analyze the articles presented over the first ten years of SBPJor conferences (2003-2013) and compare them with the ones presented during the first ten years of Journalism Workgroup for the Association of Postgraduate Programs in Communication (COMPÓS), (MACHADO; SANT'ANNA, 2014).

We analyzed the papers available on the Research Room 
section of the SBPJor website. We adopted the same four categories of analysis used for the articles presented at the COMPÓS Journalism Section (MACHADO; SANT'ANNA, 2014): types of research; the accuracy of formal standardization; the methodological references used; and the writers' level of training. In order to evaluate the type of research, we classified the articles as: essay, theoretical research, empirical research, and applied research. For formal accuracy, we looked at the analysis to determine if the papers had been divided into parts and if they had an introduction, conclusion, keywords, abstract, and bibliography. We also determined whether the methodology was explained in the abstract or in the body of the text. For the methodological references, we collected the prevalent papers to determine if they pertained to the field of Communication and Journalism, or if they were from other scientific fields. Lastly, we classified the researchers according to their level of education: PhD, Doctoral student, Master's Degree or Master's Degree student, and university graduate.

Many of the 104 articles presented at the COMPÓS Journalism Section between 2000 and 2010 (MACHADO; SANT'ANNA, 2014) used methodological methods from outside the field of Journalism, lacked formal standardization, and inadequately explained the methodology used - and most of the authors held a PhD. This paper - excluding the presentation, conclusions, and references - is divided into four parts: the prevalence of empirical research throughout the papers, the methodological shortcomings among journalism researchers, the dependence on external methodological theory methods, and a community of mainly PhD holders.

We will discuss the following main findings: 1) empirical research representing almost half of the papers; 2) the papers that with little or no formal standardization, particularly when defining and explaining the applied methodologies; 3 ) the majority of authors being PhD holders, which shows us that the scientific community has a superior academic background. As previously mentioned, some of the results are very similar to those from the articles submitted to the COMPÓS Journalism Section. This shows that they are structural characteristics of scientific papers from researchers in Brazilian journalism. 


\section{The prevalence of empirical research in the papers}

Out of the 509 total papers presented to the SBPJor between 2003 and 2007, 226 were based on empirical research (44.4\%). The table below shows the prevalence of empirical research in every year, except 2007. 215 of the total papers are essays (42.2\%) and only 68 are theoretical studies (13.3\%). There were 61 articles in 2003; 23 essays (37.7\%), 33 empirical studies (54.09\%), and five theoretical studies (8.19\%). In 2004, empirical research was the most frequently used method but did experience a slight decrease in its numbers (from $54.09 \%$ to $44.6 \%$ ). Out of the 94 papers presented, we identified 35 essays (37.23\%), 42 empirical studies (44.68\%), and 17 theoretical studies (18.08\%).

Table 1 -Research Types - SBPJor (2003-2007)

\begin{tabular}{|c|c|c|c|c|}
\hline Year & Essay & Empirical & Theoretical & Applied \\
\hline 2003 & $23(37.7 \%)$ & 33 (54\%) & $5 \quad(8.1 \%)$ & --------------- \\
\hline 2004 & 35 (37.2\%) & 42 (44.6\%) & $17(18 \%)$ & ---------------- \\
\hline 2005 & 58 (45.3\%) & 58 (45.3\%) & 12 (9.4\%) & 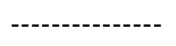 \\
\hline 2006 & $50(44.6 \%)$ & 51 (45.5\%) & 11 (9.8\%) & -------------- \\
\hline 2007 & 49 (42.9\%) & 42 (36.8\%) & $23(20.3 \%)$ & -------------- \\
\hline
\end{tabular}

Source: Author's own.

In 2005, the number of empirical studies and essays was the same at 58 each (45.3\%). There were only 12 theoretical studies conducted (9.4\%). There were 112 articles presented at the SBPJor in 2006: 50 essays (44.6\%), 58 empirical studies (45.5\%) and 11 theoretical studies (9.8\%). There was no more than a $1 \%$ difference in both the number of essays and the number of theoretical studies conducted in 2005 and 2006, yet in 2007, the data shows that the number of trials increased by $6.1 \%$. The only year which registered a lower number of empirical studies than trials was 2007; there were 49 trials (42.9\%) compared to 42 empirical studies (36.8\%). There was also a significant increase in the number of theoretical studies [11 papers (9.8\%)] as compared to previous years.

The first four of these statistics are quite relevant and justify the findings from the articles in the COMPÓS Journalism Workgroup. The first point is that, despite the reversal of positions 
in 2007, most of the studies are empirical in nature (44.4\%), different from the hegemony of essays which up until the beginning of the 1970s had dominated the studies in the field, as Marques de Melo reported (MARQUES DE MELO, 1972, MACHADO; SANT'ANNA, 2014).

Further justification comes from the fact that the most often used methodologies (discourse analysis, content analysis, studies on news production and scheduling, and case studies) depend on the objective analysis provided by empirical studies (Yin, 2003). Secondly, the large percentage of essays (42.2\%), a clear example of how important the methodological and theoretical methods in the Humanities are throughout communication studies (BUARQUE DE HOLANDA, 2005, p. 285), demonstrates that even though empirical studies are continually advancing, essays still play an important role for Brazilian researchers.

Thirdly, the low percentage of theoretical studies (13.3\%) on the epistemology of Journalism or on the methodological specifics of research in the field is noteworthy. Of course, any one of these research methods is capable of contributing towards a theoretical and methodological discussion on Journalism (ZELIZER, 2004) but, in general, most empirical studies are descriptive (SOUSA, 2004; 2006) and essays are not systematic enough to propose theoretical generalizations.

Considering that this type of research is essential towards solidifying Journalism as a scientific discipline (GROTH, 2011; MACHADO, 2005; 2010), then it goes without saying that the post-graduation programs in Journalism, more specifically, in Communication, should encourage future doctoral and Master's degree students to develop research projects which discuss Journalism from a theoretical and methodological point of view (HANITZSCH, 2006, BENETTI; LAGO, 2007, WAHL-JORGENSEN; HANITZSCH, 2009, PATTERSON, 2013).

Lastly is the lack of applied research, an indication of a kind of schizophrenia in the field of journalism science. If this occurs in Applied Social Sciences, then it is completely ineffective at meeting the demands of journalism companies or social organizations due to the development of new techniques, methodologies, processes, and products (LÖFFELHOLZ; WEAVER, 2008, MACHADO, 2008, MACHADO; TEIXEIRA, 2016).

\section{Journalism researchers' methodological shortcomings}


Table 2 - Formal Standardization 2003-2007- SBPJor

\begin{tabular}{|c|c|c|c|c|c|c|}
\hline & $\begin{array}{c}\text { Formal } \\
\text { Standar- } \\
\text { dization }\end{array}$ & Abstract & $\begin{array}{c}\text { Division } \\
\text { in parts }\end{array}$ & Conclusion & $\begin{array}{c}\text { Methodo- } \\
\text { logical } \\
\text { references }\end{array}$ & $\begin{array}{c}\text { Introduc- } \\
\text { tion }\end{array}$ \\
\hline YES & $\begin{array}{c}141 \\
(27.7 \%)\end{array}$ & $\begin{array}{c}495 \\
(97.2 \%)\end{array}$ & $\begin{array}{c}458 \\
(89.9 \%)\end{array}$ & $\begin{array}{c}332 \\
(65.2 \%)\end{array}$ & $\begin{array}{c}496 \\
(97.2 \%)\end{array}$ & $\begin{array}{c}376 \\
(73.8 \%)\end{array}$ \\
\hline NO & $\begin{array}{c}368 \\
(72.2 \%)\end{array}$ & $\begin{array}{c}14 \\
(2.7 \%)\end{array}$ & $\begin{array}{c}51 \\
(10 \%)\end{array}$ & $\begin{array}{c}177 \\
(34.7 \%)\end{array}$ & $14(2.7 \%)$ & $133(26 \%)$ \\
\hline
\end{tabular}

Source: Author's own.

After identifying the types of studies conducted by researchers in SBPJor conferences, we then looked at the survey to determine how exact their applied methodology was. We analyzed all the papers to determine if they complied with the technical standards for academic articles recommended by the Brazilian National Standards Organization (ABNT). In other words, if they had an abstract, introduction, conclusion, keywords, references, and if they were divided into parts.

The results showed only 141 papers complied with the formal standards (27.7\%) while 368 did not comply with any (72.2\%). Out of these 368 articles, 138 did not have keywords (27\%), 51 were not divided in parts (10\%), 133 did not have an introduction (26\%), 177 did not have a conclusion (34.7\%), 14 did not have an abstract (2.7\%), and nine did not have bibliographical references (1.7\%).

Furthermore, we found 131 articles with introductions that did not comply with the technical standard (25.7\%), 78 had non-compliant conclusions (15.3\%), ten had non-compliant references (1.9\%), and 14 did not list any methodological references in the bibliography (2.7\%). These results are, once again, similar to those identified in the study on the COMPÓS Journalism Section between 2000 and 2010.

As Machado and Sant'ana (2014) stated, it is undeniable that researchers in journalism are not receiving sufficient methodological training; something which needs to be corrected otherwise there will be serious consequences for professionals and the legitimacy of the field of science. We raised three hypotheses which might help explain this shortcoming: the reduced number of researchers trained in scientific initiation programs, inaccuracy among researchers in the field, and a lack of methodological and theoretical disciplines in post-graduation programs. In 2003, only one of the 61 papers followed proper formal 
standardization. We noticed that the percentage of articles with proper standardization increased over the course of the five-year period of analysis, reaching a total of 51 articles out of the 114 in 2007 . We also observed that all the bibliographies from the papers in 2004 and 2005 had some methodological reference, yet in 2003, 6.5\% did not list any, in 2006 that number was $2.7 \%$, and in $2007,6.1 \%$. What's more is that a large number of articles did not have a conclusion; $26.22 \%$ in 2003 , $36.1 \%$ in 2004, 32.8\% in 2005, $41 \%$ in 2006, and 34\% in 2007.

Many of the articles from 2003 (96.72\%), 2004 (48.93\%) and 2005 (25.7\%) did not have keywords. 2006 and 2007 showed considerable improvement in this area as all the articles met this prerequisite. Also of note is that in 2004, 14 papers did not have abstracts (14.8\%), yet all the papers from the previous years did. Two articles, one from 2003 and one from 2006, did not have bibliographical references, not even in the footnotes. This number increased to seven in 2007 , representing $6 \%$ of the articles presented that year.

These formal shortcomings are serious because one of the objectives of scientific study is to publish its findings, but these articles which are being submitted and presented to SBPJor conferences do not meet the minimum requirements established by indexed scientific journals. Even though the increase in the percentage of papers with proper standardization has been respectable over the last five years, it remains at an unsatisfactory level because more than half of the articles do not comply with the standard recommended format. SBPJor has a model of an article available for researchers to use as a guide; one of the measures it has taken to make sure studies are submitted in accordance with the standard format.

Table 3 - Methodological Explanation 2003-2007

\begin{tabular}{|l|l|l|l|l|}
\hline & $\begin{array}{c}\text { Only in the } \\
\text { abstract }\end{array}$ & $\begin{array}{c}\text { Only in the } \\
\text { body of text }\end{array}$ & $\begin{array}{l}\text { In the abstract } \\
\text { and the body }\end{array}$ & None \\
\hline 2003 & $3.27 \%$ & $11.47 \%$ & $47.54 \%$ & $37.70 \%$ \\
\hline 2004 & $17.02 \%$ & $17.02 \%$ & $29.78 \%$ & $36.17 \%$ \\
\hline 2005 & $16.5 \%$ & $21 \%$ & $32 \%$ & $30.4 \%$ \\
\hline 2006 & $17.8 \%$ & $12.5 \%$ & $42.8 \%$ & $26.7 \%$ \\
\hline 2007 & $22.8 \%$ & $8, . \%$ & $46 \%$ & $21.9 \%$ \\
\hline
\end{tabular}

Source: Author's own.

Besides the basic formal characteristics such as a title, an 
abstract, keywords, division into parts, an introduction, and a conclusion, we analyzed the methodological explanation. With the exception of 2004, the majority of the articles in all the other years explained their methodology in the abstract and the body (Table 3). We still found a large number of articles which did not explain their methodology at all. Out of the 509 articles presented between 2003 and 2007, 151 of them (29.6\%) did not explain their methodology. Out of the 358 articles (70.3\%) that did explain their methodology, 199 explained it in the abstract and the body (39\%), 85 only in the abstract (16.6\%), and 74 only in the body (14.5\%). The methodological explanation, as stated in Machado and Sant'anna (2014), demonstrates a scientific maturity and is a requirement for proving results and reproducing them in other empirical objects.

\section{Dependence on external methodological and theoretical methods}

We used previous studies (MACHADO, 2010, MACHADO; SANT'ANNA, 2014, MACHADO; SANTA CRUZ, 2015) to point out the dependence on using external methodological and theoretical methods in the field of scientific Journalism, something Groth (2011) characterized as auxiliary disciplines. We analyzed the authors who researchers in Journalism cited the most in order to identify the predominant methodological and theoretical methods in the field of science; the same way we analyzed papers from COMPÓS Journalism Section between 2000 and 2010. Overall, out of the five, ten mostcited authors, two of them cited authors from communication, two from general, and only one cited authors from journalism.

Three of these statistics reveal Journalism researchers' propensity to rely on more general scientific disciplines such as sociology, history, linguistics, and cyber culture (GROTH, 2011, ZELIZER, 2004, LÖFFELHOLZ; ROTHENBERGER, 2011). Not once in the five years were these ten most cited authors referenced less than $30 \%$ of the time, and twice they were referenced at or more than 50\%; in 2004 it was $66.6 \%$, and in 2007, 50\%. In two of the years the most-cited authors came from communication, with high percentages of $44.82 \%$ in 2003 and $40 \%$ in 2006 . Even in the single year where the most cited references came from authors within the field of journalism, the percentage did not exceed $50 \%$.

Table 4 - Methodological Methods 


\begin{tabular}{|l|l|l|l|}
\hline \multicolumn{1}{|c|}{ YEAR } & \multicolumn{1}{|c|}{ General } & \multicolumn{1}{|c|}{ Journalism } & Communication \\
\hline 2003 & $31.03 \%$ & $21.83 \%$ & $44.82 \%$ \\
\hline 2004 & $66.66 \%$ & $22.91 \%$ & $10.43 \%$ \\
\hline 2005 & $30 \%$ & $50 \%$ & $20 \%$ \\
\hline 2006 & $30 \%$ & $30 \%$ & $40 \%$ \\
\hline 2007 & $50 \%$ & $40 \%$ & $10 \%$ \\
\hline
\end{tabular}

Source: Author's own.

The ten most-cited authors in methodological and theoretical references work in the fields of Journalism, Sociology, Linguistics, Cyber Culture, Literary Theory, Discourse Analysis, Communication, and Philosophy. In every one of the five years at least three of the most cited authors come from journalism. Even more interesting is that, with the exception of one year (2003), the author who was referenced the most comes from journalism; Professor Nelson Traquina from the New University of Lisboa. In 2003 (the one year where he was not the most cited author) he was the second most cited. The other most cited researchers in Journalism were: Jorge Pedro Sousa (third in 2003, eighth in 2004, and fifth in 2006); Nilson Lage (fifth in 2005 and ninth in 2006); Elias Machado (tenth in 2003, ninth in 2005, and seventh in 2007); Marques de Melo (sixth in 2005); Alfredo Vizeu (sixth in 2007); and Ciro Marcondes Filho (eighth in 2007).

Table 5 - Most cited authors by researchers

\begin{tabular}{|c|c|c|c|c|c|c|c|c|c|c|}
\hline YEAR & \multicolumn{10}{|c|}{ TEN MOST CITED AUTHORS BY RESEARCHERS } \\
\hline 2003 & $\begin{array}{l}\text { Mauro } \\
\text { Wolf }\end{array}$ & $\begin{array}{l}\text { Nelson } \\
\text { Tra- } \\
\text { quina }\end{array}$ & $\begin{array}{l}\text { Jorge } \\
\text { Pedro } \\
\text { Sousa }\end{array}$ & Pierre Levy & $\begin{array}{l}\text { Stuart } \\
\text { Hall }\end{array}$ & $\begin{array}{l}\text { Néstor } \\
\text { Garcia } \\
\text { Canclini }\end{array}$ & $\begin{array}{l}\text { Manuel } \\
\text { Castells }\end{array}$ & $\begin{array}{l}\text { George } \\
\text { Landow }\end{array}$ & $\begin{array}{l}\text { Pierre } \\
\text { Bour- } \\
\text { dieu }\end{array}$ & $\begin{array}{l}\text { Elias } \\
\text { Macha- } \\
\text { do }\end{array}$ \\
\hline 2004 & $\begin{array}{l}\text { Nelson } \\
\text { Traquina }\end{array}$ & $\begin{array}{l}\text { Mauro } \\
\text { Wolf }\end{array}$ & $\begin{array}{l}\text { Pierre } \\
\text { Bour- } \\
\text { dieu }\end{array}$ & $\begin{array}{l}\text { Dominique } \\
\text { Maingue- } \\
\text { neau }\end{array}$ & $\begin{array}{l}\text { Roland } \\
\text { Barthes }\end{array}$ & $\begin{array}{l}\text { Manuel } \\
\text { Castells }\end{array}$ & $\begin{array}{l}\text { Norman } \\
\text { Fairclough }\end{array}$ & $\begin{array}{l}\text { Jorge } \\
\text { Pedro } \\
\text { Sousa }\end{array}$ & $\begin{array}{l}\text { Eni } \\
\text { Orlandi }\end{array}$ & $\begin{array}{l}\text { Her- } \\
\text { bert } \\
\text { Gans }\end{array}$ \\
\hline 2005 & $\begin{array}{l}\text { Nelson } \\
\text { Traquina }\end{array}$ & $\begin{array}{l}\text { Pierre } \\
\text { Bour- } \\
\text { dieu }\end{array}$ & $\begin{array}{l}\text { Mauro } \\
\text { Wolf }\end{array}$ & $\begin{array}{l}\text { Roland } \\
\text { Barthes }\end{array}$ & $\begin{array}{l}\text { Nilson } \\
\text { Lage }\end{array}$ & $\begin{array}{l}\text { José } \\
\text { Marques } \\
\text { de Melo }\end{array}$ & $\begin{array}{l}\text { Mikhail } \\
\text { Bakhtin }\end{array}$ & $\begin{array}{l}\text { Manuel } \\
\text { Castells }\end{array}$ & $\begin{array}{l}\text { Elias } \\
\text { Macha- } \\
\text { do }\end{array}$ & $\begin{array}{l}\text { Cremil- } \\
\text { da } \\
\text { Medina }\end{array}$ \\
\hline 2006 & $\begin{array}{l}\text { Nelson } \\
\text { Traquina }\end{array}$ & $\begin{array}{l}\text { Pierre } \\
\text { Bour- } \\
\text { dieu }\end{array}$ & $\begin{array}{l}\text { Edgar } \\
\text { Morin }\end{array}$ & $\begin{array}{l}\text { Michel } \\
\text { Foucault }\end{array}$ & $\begin{array}{l}\text { Jorge } \\
\text { Pedro } \\
\text { Sousa }\end{array}$ & $\begin{array}{l}\text { Mikhail } \\
\text { Bakhtin }\end{array}$ & $\begin{array}{l}\text { Lucia } \\
\text { Santaella }\end{array}$ & $\begin{array}{l}\text { Mauro } \\
\text { Wolf }\end{array}$ & $\begin{array}{l}\text { Nilson } \\
\text { Lage }\end{array}$ & $\begin{array}{l}\text { Roland } \\
\text { Barthes }\end{array}$ \\
\hline 2007 & $\begin{array}{l}\text { Nelson } \\
\text { Traquina }\end{array}$ & $\begin{array}{l}\text { Pierre } \\
\text { Bour- } \\
\text { dieu }\end{array}$ & $\begin{array}{l}\text { Eni } \\
\text { Orlan- } \\
\text { di }\end{array}$ & $\begin{array}{l}\text { Mauro } \\
\text { Wolf }\end{array}$ & $\begin{array}{l}\text { Mikhail } \\
\text { Bakhtin }\end{array}$ & $\begin{array}{l}\text { Alfredo } \\
\text { Vizeu }\end{array}$ & $\begin{array}{l}\text { Elias } \\
\text { Machado }\end{array}$ & $\begin{array}{l}\text { Marcon- } \\
\text { des } \\
\text { Filho }\end{array}$ & $\begin{array}{l}\text { Michel } \\
\text { Fouca- } \\
\text { ult }\end{array}$ & $\begin{array}{l}\text { Jurgen } \\
\text { Haber- } \\
\text { mas }\end{array}$ \\
\hline
\end{tabular}

Source: Author's own.

Further relevant authors from other disciplines are: Mauro 
Wolf from Italy (Communication) who was one of the most cited authors over the five years. He came in at first in 2003 , second in 2004 , third in 2005, eighth in 2006, and fourth in 2007. As you can see, he is one of the more consistently referenced authors. In second place is Pierre Bourdieu from France (Sociology). He came in at seventh in 2003, third in 2004, and second between 2005 and 2007. In third place are the two authors who were cited in three of the five years. They are Manuel Castells (Sociology) and Roland Barthes (Communication). Castells was seventh in 2003, sixth in 2004, and eighth in 2005; Barthes was fifth in 2004, fourth in 2005, and tenth in 2006.

Michel Foucault (Discourse Analysis) was cited in two of the five years and came in at fourth in 2006 and ninth in 2007; Eni Orlandi (Discourse Analysis) ninth in 2004 and third in 2007; and Mikhail Bakhtin (Philosophy of language) sixth in 2006 and fifth in 2007. The authors who were cited only once were Pierre Levy (Cyber Culture), fourth in 2003; Stuart Hall (Cultural Studies), fifth in 2003; Néstor Garcia Canclini (Anthropology), sixth in 2003; George Landow (Literary Theory), eighth in 2003; Dominique Maingueneau (Discourse Analysis), fourth in 2004; Norman Fairclough (Linguistics), seventh in 2004; Herbert Gans (Sociology), tenth in 2004; Lucia Santaella (Communication), seventh in 2006; and Jurgens Habermas (Philosophy), tenth in 2007.

\section{A community dominated by PhD holders}

The previous article (MACHADO; ROHDEN, 2014) shows two trends which started in 2003 and 2004 and continued until 2007: most of the papers were written individually by authors holding PhD degrees. Among the 509 articles presented over the first five years at SBPJor, 431 were written individually (84.6\%) while only 78 were collective projects (15.3\%). 192 of the individual papers were written by PhDs (37.7\%), 84 by doctoral students (16.5\%), 63 by Master's degree students (12.3\%), 80 by Master's degree holders (15.7\%), and 12 by graduates (2.3\%). The predominance of doctoral authors confirms the results from the COMPÓS Journalism Section (MACHADO; SANT'ANNA, 2014) 
Table 6 - Individual and collective papers

\begin{tabular}{|l|c|c|}
\hline YEAR & Collective Papers & Individual Papers \\
\hline 2003 & $19.6 \%$ & $80.3 \%$ \\
\hline 2004 & $13.8 \%$ & $86.1 \%$ \\
\hline 2005 & $13.3 \%$ & $86.7 \%$ \\
\hline 2006 & $17 \%$ & $83 \%$ \\
\hline 2007 & $14.9 \%$ & $85.1 \%$ \\
\hline
\end{tabular}

Source: Author's own.

Table 7 - Education level of authors of individual papers

\begin{tabular}{|l|l|l|l|l|l|}
\hline YEAR & Graduates & $\begin{array}{c}\text { Master's } \\
\text { degree } \\
\text { students }\end{array}$ & $\begin{array}{c}\text { Master's } \\
\text { degree } \\
\text { holders }\end{array}$ & $\begin{array}{c}\text { Doctoral } \\
\text { students }\end{array}$ & PhDs \\
\hline 2003 & $4.9 \%$ & $16.3 \%$ & $11.4 \%$ & $13.1 \%$ & $34.4 \%$ \\
\hline 2004 & $3.1 \%$ & $9 . \%$ & $19.1 \%$ & $10.6 \%$ & $43.6 \%$ \\
\hline 2005 & $3.1 \%$ & $13.2 \%$ & $17.9 \%$ & $18.7 \%$ & $33.5 \%$ \\
\hline 2006 & $0.9 \%$ & $12.5 \%$ & $13.4 \%$ & $18.7 \%$ & $37.5 \%$ \\
\hline 2007 & $0.8 \%$ & $11.4 \%$ & $14.9 \%$ & $18.4 \%$ & $39.4 \%$ \\
\hline
\end{tabular}

Source: Author's own.

61 papers were presented in 2003, 49 individual ones (80.32\%) and 12 collective (19.67\%). Starting with the individual ones: three were written by graduates (4.91\%), ten by Master's degree students (16.39\%), eight by doctoral students (13.11\%) and 21 by PhDs (34.42\%). The collective papers presented the following data: five written by PhDs and graduate students (8.1\%), two by PhDs and Master's degree students (3.27\%), one by a PhD and a doctoral student (1.63\%), two by doctoral and graduate students (3.27\%), one by a Master's degree student (1.63\%), and one by a Master's degree student and a graduate student (1.63\%).

94 papers were presented in 2004, 81 individual (86.17\%) and 13 collective (13.82\%). Starting with the individual ones: three were written by graduates (3.19\%), nine by Master's degree students (9.57\%), 18 by Master's degree holders (19.14\%), ten 
by doctoral students (10.63\%) and 41 by PhDs (43.61\%). The collective papers presented the following data: two written by PhDs (2.12\%), one by a PhD and a Master's degree holder (1.06\%), two by PhDs and Master's degree students (2.12\%), five by PhDs and graduate students (5.31\%), one by a Master's degree holder (1.06\%), one by a Master's degree student (1.06\%), and one written in partnership between a Master's degree student and graduates (1.06\%).

128 papers were presented in 2005,111 individual (86.7\%) and 17 collective (13.3\%). Starting with the individual ones: four were written by graduates (3.1\%), 17 by Master's degree students (13.2\%), 23 by Master's degree holders (17.9\%), 24 by doctoral students (18.7\%) and 43 by PhDs (33.5\%). Of the authors we found who opted to produce collective papers, five were written by a PhD and doctoral students (3.9\%), two by a PhD and a Master's degree holder (1.5\%), one by a PhD and a graduate $(0.7 \%)$, one by a PhD and a Master's degree holder $(0.7 \%)$, one by PhDs $(0.7 \%)$, one by a doctoral student and a Master's degree student $(0.7 \%)$, one by a doctoral student and a graduate $(0.7 \%)$, one by a Master's degree holder and a Master's degree student $(0.7 \%)$, one by Master's degree holders $(0.7 \%)$, one by Master's degree students $(0.7 \%)$, one by a Master's degree holder and a graduate (0.7\%), and one collaboration between a Master's degree holder, a Master's degree student, a doctoral student, and a PhD (0.7\%).

112 articles were presented in 2006, 96 individual (83\%) and 19 collective (17\%). Starting with the individual ones: one was written by a graduate (0.9\%), 14 by Master's degree students (12.5\%), 15 by Master's degree holders (13.4\%), 21 by doctoral students (18.7\%) and 42 by PhDs (37.5\%). The collective papers presented the following data: four were written by a PhD and a doctoral student (3.5\%), one by a PhD and a Master's degree holder $(0.9 \%)$, one by a PhD and a graduate $(0.9 \%)$, one by a PhD and a graduate student (0.9\%), two by PhDs (1.7\%), five by doctoral students and Master's degree students (4.4\%), two by a Master's degree holder and Master's degree students (1.7\%), one by a Master's degree student (0.9\%), one by a Master's degree holder and a graduate $(0.9 \%)$, and one was a partnership between a Master's degree holder, a graduate, a graduate student, and a PhD (0.9\%).

114 papers were presented in 2007, 97 individual (85\%) and 
17 collective (14.9\%). Starting with the individual ones: one was written by a graduate ( $0.8 \%), 13$ by Master's degree students ( $11.4 \%$ ), 17 by Master's degree holders (14.9\%), 21 by doctoral students (18.4\%) and 45 by PhDs (39.4\%). The collective papers presented the following data: seven were written by PhDs in partnership with Master's degree students (6.1\%), two by PhDs and graduate students (1.7\%), three by only PhDs (2.6\%), one between a doctoral student and a Master's degree holder (0.8\%), one between a doctoral student and a graduate student (0.8\%), one between Master's degree holders $(0.8 \%)$, and one between a doctoral student, a Master's degree student, and a graduate $(0.8 \%)$. We could not determine the educational background of the authors for one of the collective papers (Carmen Carvalho and Ronaldo Leite).

\section{Conclusions}

After concluding this work, we are able to summarize a series of findings we consider to be relevant towards understanding the particulars of research in journalism across the country. Firstly, even though we identified a large portion of articles based on empirical research, the strong tradition of essay research and the lack of applied research are still evident. Secondly, the high percentage of papers which did not comply with the basic rules of scientific article writing is of concern. Thirdly, it is clear that Brazilian researchers continue to rely heavily on the auxiliary disciplines of journalism defined by Otto Groth (2011). Lastly, the majority of papers were authored by PhDs and presented individually. These findings are very similar to the papers presented at the COMPÓS Journalism Section from 2000 to 2010 , which raises the hypothesis that they are structural characteristics of the Brazilian field of Journalism research.

Regardless of previous studies confirming them as structural characteristics of Journalism research in the country, we believe that these results indicate what the stage of professionalization in research among journalism researchers is. The formal shortcomings which have been identified are very serious, even more concerning due to the fact that most of the researchers are PhDs. As the previous works (MACHADO; SANT'ANNA, 2014, MACHADO; ROHDEN, 2014) mentioned earlier 
state, urgent measures need to be taken by scientific associations such as SBPJor to raise the bar in evaluation processes for postgraduation courses, including the methodological disciplines in their curriculum and graduation courses. They need to encourage scientific initiation programs for graduation students in order to improve the formal quality of authored papers in the field of journalism (MACHADO; TEIXEIRA, 2016).

A few findings need a more systematic analysis in order to identify their causes. The most cited author is Professor Nelson Traquina including other prestigious names from the field including Marques de Melo, Nilson Lage, Cremilda Medina and Ciro Marcondes Filho, all of whom are being referenced more and more by today's generation. Mauro Wolf continues to be one of the main references among Journalism researchers. Pierre Bourdieu's influence is felt throughout the field and, oddly enough, contrary to what one would expect considering the overwhelming emergence of cyber journalism over the last decade, authors such as Pierre Levy, George Landow, and Manuel Castells are not often cited, even though they are included in the list of ten most cited authors. Thanks to Nelson Traquina and another Portuguese, Jorge Pedro Sousa, being the most respected authors among those in the top ten cited, we can see that although the institution is a more recent one, the Portuguese school serves as a methodological and theoretical reference for Brazilian researchers (MACHADO; SANTA CRUZ, 2015 ).

*This paper was translated by Lee Sharp.

\section{REFERENCES}

BARDIN, Laurance. Análise de conteúdo. Análise de conteúdo. Lisboa: Edições 70, 1995.

BAKHTIN, Mikhail. Marxismo e filosofia da linguagem. Tradução de Marian Yagello. São Paulo: HUCITEC, 1986.

BARTHES, Roland. A aventura semiológica. Tradução de Maria Santa Cruz. Lisboa: Edições 70, 1987, Coleção Signos.

BENETTI, Marcia: LAGO, Claudia (Eds.). Metodologia de pesquisa em 
Jornalismo. Petrópolis: Vozes, 2007.

BUARQUEDE HOLANDA, Sergio. Raízes do Brasil. Edição comemorativa. SCHWARCZ, Lilian Moritz; DE ARAUJO, Ricardo Benzaquen (Eds.). São Paulo: Companhia da Letras, 2016.

BOURDIEU, Pierre. Sobre a televisão. Seguido de A influência do Jornalismo e Os jogos Olímpicos. Rio de Janeiro: Zahar Editores, 1997.

CANCLINI, Néstor García. Culturas Híbridas. Estratégias para entrar e sair da modernidade. Tradução de Ana Regina Lessa e Heloísa Pezza Cintrã. São Paulo: EDUSP, 1997.

CASTELLS, Manuel. A era da informação: Economia, Sociedade e Cultura. v. 1 : A sociedade em rede. Tradução de Roneide Venancio Majer. São Paulo: Paz e Terra, 2000.

FAIRCLOUGH, Norman. Discourse and Social Change. Cambridge: Polity Press, 1993.

FOUCAULT, Michel. A Ordem do Discurso. Aula inaugural no Cóllege de France pronunciado em 2 de Dezembro de 1970. São Paulo: Loyola, 1996.

GANS, Herbert. Deciding What's News. A Study of CBS Evening News, NBC Nightly News, Newsweek and Time. New York: Pantheon Books, 1979.

GROTH, Otto. O poder cultural desconhecido. Fundamentos da ciência dos jornais. Tradução de Liriam Sponholz. Petrópolis: Vozes, 2012.

HABERMAS, Jurgen. Mudança Estrutural da Esfera Pública. Rio de Janeiro: Tempo Brasileiro, 1984, Biblioteca Tempo Brasileiro.

HALL, Stuart et al. A produção das notícias: o mugging nos media. IN: TRAQUINA, Nelson. (Ed.). Jornalismo: questões, teorias e "estórias". Lisboa: Vega, 1993, p. 224-248.

HANITZSCH, Thomas. Journalism Research in Germany: Origins, theoretical innovations and future outlook. Brazilian Journalism Research. V. 2, n. 1 (2006), 39-53.

LAGE, Nilson. Ideologia e Técnica da notícia. Florianópolis: Insular, 2001.

LANDOW, George. Hyper/Text/Theory. Baltimore, Maryland: Johns Hopkins University Press, 1994.

LEVY, Pierre. As tecnologias da inteligência. O future do pensamento na era da informática. São Paulo: Editora 34, 1995. 
LÖFFELHOLZ, Martin; WEAVER, David (Eds). Global Journalism Research. Theories, Methods, Findings and Future. London: Wiley-Blackwell, 2008.

LÖFFELHOLZ, Martin; ROTHENBERGER, Liane. Eclectic Continuum, Distinct Discipline or Sub-Domain of Communication Studies? Theoretical considerations and empirical findings on the disciplinarity, multidisciplinarity and transdisciplinarity of journalism studies. Brazilian Journalism Research, 7 (2011), 1, p. 7-29.

MACHADO, Elias. From Journalism Studies to Journalism Theory. Brazilian Journalism Research, v. 1, n. 1 (2005), 11-23.

MACHADO, Elias. O Jornalismo Digital em Bases de Dados. Florianópolis: Calandra, 2008.

MACHADO, Elias. Journalism Research Methodologies: A historical review and prospects for the production of guidance manuals. Brazilian Journalism Research v. 6, n.1 (2010), 10-28

MACHADO, Elias; ROSA SILVA, Tainara. Metodologias de Pesquisa Aplicadas ao Jornalismo: Um estudo dos manuais de referência (1970-2007). Anais do Congresso Brasileiro de Ciências da Comunicação, FADEP: Foz do Iguaçu, 2014, 14 pp.

MACHADO, Elias; SANT'ANNA, Jéssica. Limitações metodológicas na pesquisa em Jornalismo: Um estudo dos trabalhos apresentados no GT de Jornalismo da COMPÓS (2000-2010). Pauta Geral - Revista Brasileira de Jornalismo, v.1, nº1, (2014), 29-45.

MACHADO, Elias; ROHDEN, Julia. Metodologias de pesquisa aplicadas ao jornalismo: um estudo dos trabalhos apresentados na SBPJor (20032004). Anais do $12^{\circ}$ Encontro Nacional de Pesquisadores em Jornalismo. Santa Cruz do Sul: Universidade de Santa Cruz do Sul, 2014, 15 pp.

MACHADO, Elias; SANTA CRUZ, Andressa. Manuais de pesquisa em jornalismo. (Estudo de tipos, matrizes metodológicas e de autores de referência nas obras de Otto Groth e Jorge Pedro Sousa). Anais do XXXVIII Congresso Brasileiro de Ciências da Comunicação. Rio de Janeiro: Universidade Federal do Rio de Janeiro, 2015, p. 21. Available at: http://portalintercom.org.br/anais/nacional2015/ indiceautor.htm\#E

MACHADO, Elias. TEIXEIRA, Tattiana. Innovation as an essential part of journalism education in contemporary societies. Journal of Applied Journalism \& Media Studies, 2016.

MAINGUENEAU, Dominique. Novas tendências em análise do discurso. Campinas, Pontes, 1989.

MARCONDES FILHO, Ciro. Jornalismo e Comunicação. A saga dos cães 
perdidos. São Paulo: Hacker editores, 2000.

MARQUES DE MELO, José. Estudos de Jornalismo Comparado. São Paulo: Pioneira, 1972.

ORLANDI, Eni. As formas do silêncio. No movimento dos sentidos. Campinas: Unicamp, 1992

ORLANDI, E. Análise de Discurso: princípios e procedimentos. Campinas, São Paulo: Pontes, 2001.

PATTERSON, Thomas, E. Informing the news. The need for knowledgebased journalism. New York, Vintage Books, 2013.

PÊCHEUX, Michel. Semântica e Discurso: uma crítica à afirmação do óbvio. Tradução: Eni Puccinelli Orlandi. et al. Campinas, SP: Editora da Unicamp, 1988.

SANTAELLA, Maria Lúcia. Comunicação e Pesquisa. São Paulo: Hacker Editores, 2001.

SOUSA, Jorge Pedro. Introdução à análise do Discurso Jornalístico Impresso: um guia para estudantes de graduação. Florianópolis: Letras contemporâneas, 2004.

SOUSA, Jorge Pedro. Elementos de Teoria e Pesquisa da Comunicação e dos Media. Porto; Edições Universidade Fernando Pessoa, 2003, 2 a edição revista e ampliada. Porto: EUFP, 2006.

TRAQUINA, Nelson. O estudo do jornalismo no século XXI. São Leopoldo: Unisinos, 2001.

TRAQUINA, Nelson. O que é Jornalismo. Lisboa: Quimera, 2002.

WAHL-JORGENSEN, Karin \& HANITZSCH,Thomas (eds. ) Handbook of Journalism Studies. New York: Routledge, (2009).

WOLF, Mauro. Teorias da comunicação. Lisboa: Presença 1987

ZELIZER, Barbie. Taking Journalism Seriously: News and the Academy. London: SAGE, 2004

YIN, Robert. Case Study Research: Design and Methods. Thousand Oaks: Sage, 2003. 
Elias Machado is Associate professor at the Federal University of Santa Catarina, Brazil. Doctor in Journalism from the Autonomous University of Barcelona, Spain. Former president of the Brazilian Association of Researchers in Journalism (SBPJor). One of the pioneers in online journalism studies in Brazil, participated in the creation of the Research Group in Journalism Online (GJOL) - http:// www.gjol.net - in 1995. It develops research on journalism education, research methodologies in journalism and theories of journalism. He has published articles in journals such as Brazilian Journalism Research, Communicatio: South African journal for communication theory and research and Pauta Geral - Brazilian Journal of Journalism.

Julia Rohden is Journalism undergraduate student at the Federal University of Santa Catarina and fellow Scientific Initiation of CNPq in the Group of Applied Research in Journalism (LAPJor) - http://www.lapjor.cce.ufsc.br 